\title{
THE INTERACTION BETWEEN INDIVIDUAL CHARACTERISTICS AND MODE OF WORK IN PREDICTING RESILIENCE AND JOB SATISFACTION
}

\author{
Janina Gašperlin \\ School of Economics and Business, University of Ljubljana \\ janina.gasperlin@gmail.com
}

\begin{abstract}
Nuša Dovžan
School of Economics and Business, University of Ljubljana
\end{abstract} nusad@icloud.com

Karmen Ferjan

School of Economics and Business, University of Ljubljana karmenferjankarmen@gmail.com

\section{Amadeja Lamovšek}

School of Economics and Business, University of Ljubljana amadeja.lamovsek@ef.uni-lj..si

\begin{abstract}
Since the COVID-19 virus has become part of our lives, organizations have been looking for ways to adjust work arrangements and adopt different modes of work (e.g., hybrid and remote work) while maintaining job satisfaction among their employees. This paper explored the relationships between employee's personality traits and their mindset and their influence on employee resilience and job satisfaction. Additionally, we investigated whether the relationship between personality traits, employee mindset, and desired outcomes varied across different modes of work. This study is important for managers because it helps them better understand the importance of their employees' individual characteristics in relation to desired outcomes.
\end{abstract}

Keywords: personality traits, resilience, mindset, job satisfaction, mode of work

\section{INTRODUCTION}

The COVID-19 pandemic is currently reshaping our world and impacting not only our personal lives, but our work lives as well. The way we work is changing from the office to hybrid or even completely remote workplaces, and different people are reacting differently to all the changes and protective measures (Shokrkon \& Nicoladis, 2021). Job satisfaction has an impact on material advantage and well-being. Em- ployees who are happier at their jobs are more satisfied, and their performance is affected positively, which is why job satisfaction is relevant and needs to be explored (Adigun, Oyekunle \& Onifade, 2017). Resilience is another important factor, because there is clear evidence that more-resilient people are able to bounce back from difficult experiences, adapt, develop, and in some cases even grow (Luthans, Vogelgesang \& Lester, 2006). Many employers are focusing increasingly on the critical factors that influ- 
ence a company's resilience, and resilience seems to be as important to companies as the bottom line (Noopur, 2021). Despite clearly being recognized as salient, many factors that potentially can impact job satisfaction and resilience have not been studied yet and need to be explored further.

Some studies have shown the relationship between employee personality traits and their impact on job satisfaction and resilience. For example, recent research has found that extraverts are more prone to depression (Wijngaards, Sisouw de Zilwa \& Burger, 2020), and that people with a positive attitude cope better with current circumstances (Fuller \& Huseth-Zosel, 2021). In a study of the Latvian National Guard, extraverted employees were found to be less resilient than introverts (Kalinnikova, Zavodilov \& Dmitrijeva, 2020), which could mean that introverts experience far less stress due to their resilience. In addition, one study showed that people with a positive mindset have higher job satisfaction (Orkibi \& Brandt, 2015). Luthans and Youssef (2007) found a positive correlation between the contribution of hope, optimism, and resilience (i.e., elements of positive psychological capital or positive mindset) and job satisfaction and job happiness. Due to recent developments in the environment in which COVID19 circumstances have evolved suddenly, the topic also is quite new and unexplored, and as such provides a unique opportunity for scientific insight.

The literature does not give us answers to the question of what happens when subjects are not exposed to extreme conditions as in the study by Kalinnikova et al. (2020), but are observed in their natural environment. Moreover, no clear study has confirmed that introverts are more resilient when exposed to any kind of stressful situation (e.g., the COVID-19 situation). Wei (2020) showed that introverts actually reported worse psychological changes than extraverts as a result of the pandemic (i.e., a stressful situation) and had higher levels of depression, anxiety, and loneliness. Because of these conflicting claims, we determined which of these claims proves to be true. In addition, many studies focused on the effects of a positive mindset on performance, which of course is relevant for organizations, but they focused less on the effects on job satisfaction, which we also believe is important and should be researched more. We also found a lack of research on the correlation between employee positivity or negativity and organizational resilience, and because this currently is a hot topic and a desirable trait, we explored this in greater depth. Finally, to the best of our knowledge, no research has addressed whether the relationship between personality traits, employees' mindsets, and desired outcomes varies across different modes of work.

Our study explored interrelationships among employees' personality traits, their mindset, and how they affect their resilience and job satisfaction, in the hope of finding clues about which type of trait might be more successful in coping with stress, and whether any of these traits are better predictors of employees' resilience. This could make an important contribution to the scholarly discussion initiated by Cain (2012) regarding the strength of introverts in the workplace and their job satisfaction. By conceptualizing and testing our model, organizations can gain perspective on the importance of positivity in the workplace and can educate their employees toward a more positive attitude.

This study advances the research area examining personality traits and their effects on job satisfaction and resilience. We wanted to find out whether more-extraverted people are more resilient, because studies in this area seem to be contradictory (Kalinnikova et al., 2020; Wei, 2020). On the other hand, the research on individual mindset and resilience seems to be fairly clear, so we want to confirm findings from the existing theory. However, if the results of our research showed the opposite, this could point us in a new direction to find an optimistic aspect of pessimistic thinking within specific settings related to modes of work. Along these lines, we wanted to find out whether there is a relationship between the mode of work and workers' resilience. If such a relationship exists, our study could be an important help for many different people-managers, HR managers, employees, and others-in making decisions about how to work after the COVID-19 constraints have been relaxed. In addition, this study could be highly significant if we find a positive relationship between the mode of work and employee job satisfaction. Our study fills some gaps in the literature on the relationship between positive mindset and job satisfaction, because research on this topic is very scarce. 


\section{THEORETICAL BACKGROUND}

\subsection{Personality Traits}

Personality traits can be defined as patterns of thoughts, feelings, and behaviors that reflect how an individual tends to react in certain situations under certain circumstances (Sanchez-Roige, Gray, MacKillop, Chen \& Palmer, 2017). The five-factor model of personality was developed by several researchers (Digman, 1990) who agreed that there are five trait dimensions that capture a wide range of individual differences in personality, namely neuroticism, agreeableness, openness to experience, conscientiousness, and extraversion (Soto, Kronauer \& Liang, 2015; Roccas, Sagiv, Schwartz \& Knafo, 2002). We decided to focus on extraversion because it recently has been included in scientific debates (Shokrkon \& Nicoladis, 2021) and seems to be a topical issue.

The idea of extraversion can be depicted with a bell curve, in which introversion and extraversion are at opposite ends (Houston, 2021). People who supposedly are extraverts engage in social activities to a greater extent, prefer group activities, and become energized by social interactions (Lucas, Le \& Dyrenforth, 2008; ter Bogt, Engels \& Dubas, 2006). The opposite might be true for introverts, who tend to prefer solitary activities and easily are overwhelmed by too much stimulation from social gatherings and engagement (Goby, 2006). Both terms, introvert and extravert, were introduced by Carl Jung (1921), but his original definitions have been interpreted in various ways. He also introduced the term ambivert, which lies in the middle of the spectrum, and Conklin (1923) added that ambiverts draw energy interchangeably from both ends of the spectrum.

With the idea of a spectrum, we can say that it is difficult to create a benchmark and say when someone is introverted or extraverted. Instead, we can use the spectrum of extraversion as a scale to determine where people fall in terms of behavior compared to others (Houston, 2021). Therefore, we decided to not use the terms introvert and extravert in our study, because it is difficult to put a benchmark on a scale and categorize people into groups of introverts and extraverts based solely on the data obtained. Instead, we categorized our participants from more to less extraverted.
As attitudinal standards are much more "extraverted" these days, society has tried to cure introverts in some ways (Taylor, 2020; Lounsbury, Moffitt, Gibson, Drost \& Stevens, 2007). It has been shown that there is a relationship between extraversion and selection success (Stewart, Dustin, Barrick \& Darnold, 2008), because extraverts tend to present themselves better (Kristof-Brown, Barrick \& Franke, 2002). According to Wilmot, Wanberg, Kammeyer-Mueller \& Ones (2019), extraverts perform better in the workplace than their introverted counterparts due to their proactive nature and constant suggestions to improve their career and company. Therefore, and because they tend to earn more than their introverted counterparts (Gensowski, 2018), we could say that extraverts have the upper hand when it comes to being more satisfied with their jobs than introverts.

However, because extraverts are more likely to be satisfied in roles that involve high levels of social interaction (Huang et al., 2016), they currently are in a poor position to be completely satisfied with their jobs because the pandemic has taken away this opportunity. This was confirmed by Liu et al. (2021), who found that extraverts showed higher levels of distress due to the inability to interact socially. In addition, Kalinnikova et al. (2020) showed that introverted national guards showed lower levels of stress and thus higher levels of resilience than their extraverted counterparts. However, Wei (2020) indicated that introverts actually experienced worse psychological changes than extraverts as a result of the pandemic (i.e., a stressful situation) and exhibited higher levels of depression, anxiety, and loneliness. Taken together, these studies report conflicting information about the response of people with different personality types.

\subsection{Mindset}

Mindset is a certain belief of how someone perceives the world and themselves. There are many types of mindset (Rhinesmith, 1992). For example, Dweck (2007) distinguished between the growth mindset and the fixed mindset, which are associated with abilities. The fixed mindset is associated with innate abilities that cannot grow. A growth mindset, on the other hand, is associated with hard work that 
can lead to success. On the other hand, Sagiv and Schwartz (2007) developed a theory that there are eight types of mindsets, namely hierarchical individualism, egalitarian individualism, hierarchical synergism, egalitarian synergism, hierarchical populism, egalitarian populism, hierarchical collectivism, and egalitarian collectivism. There is a relationship between these eight types of mindsets (Yolles \& Fink, 2013). A positive mindset also can be associated with optimism, which refers to a person's future. It is about having hope for the future. Optimism has a positive impact on well-being (Carver, Scheier \& Segerstrom, 2010). In our research, we decided that the definition of positive and negative mindset was the most suitable for our research because we think that these terms are used first when we use the word mindset.

The positive mindset described in conservation of resources theory gains positive outcomes such as well-being (Hobfoll, 2011). Individuals who are more likely to have positive thinking balance work better and experience positive life outcomes. Individuals' positivity is more likely to lead to success because positive individuals are more likely to face their problems (Carver \& Scheier, 1998; Scheier \& Carver, 2003). In one study, it was found to have no effect on performance, but positive people are more determined, which can lead to better performance in the long run (Tenney, Logg \& Moore, 2015). Sagone and Caroli (2015) showed a positive correlation with resilience: individuals with a more positive attitude toward life exhibited higher resilience. People who are more positive tend to be more resilient than less positive-minded people.

\subsection{Mode of Work}

The last decade witnessed a trend of increasing use of work from home, an increasing number of digital nomads, and the formation of different modes of work. The first mode of work is a traditional office specified for employees who do their entire work at the company's physical location. The opposite is remote work, in which people can work from anywhere. Between these are two types of hybrid systems. First hybrid option is one in which the employees can choose to work from home or in the office. Another hybrid system is called hybrid rotation, in which working groups have a schedule for working in the workplace and from home or another location. As a result of the pandemic, there has been some digital transformation in most companies. There is a growing trend for companies to focus on employee well-being in the workplace and develop more-flexible working models such as hybrid systems. The question of the best way to work post-pandemic remains for many companies (Rubin, Nikolaeva, Nello-Deakin \& te Brömmelstroet, 2020).

A traditional office means that employees primarily work in a designated space on the premises of the company. (Hill, Ferris \& Märtinson, 2003). A rotation system, one of the possible hybrid systems, means that groups of students or employees rotate on a fixed schedule among different learning or working modalities. The rotation system always includes at least one station for online working or learning. One of the benefits of the rotation system is that it allows working in smaller groups. That mode of work might be the answer to dealing with the lack of facilities (Staker \& Horn, 2012). The second hybrid system arranges the employee's working location according to their preferences. In this case, work can be done partly at home and partly at the workplace (Employers' Federation of India, 2020).

"Work from home" is a term used for labour activities accessed through the use of information technology and is performed away from the traditional workplace' (Employers' Federation of India, 2020). Work from home is a subcategory of remote work, which first was defined as "periodic work away from the main office one or more days per week" either at home or from abroad (Nilles, 1998). During COVID-19, the lockdown has led to an increasing use of work from home. Companies with experiences in different types of remote work have found some advantages and disadvantages compared with working in the office. For example, Google learned that the key to successful remote work was both formal and informal communication. Employees sometimes struggled with the feeling of not being connected to the outside world, and there also were some logistical difficulties such as coordinating schedules when employees were in different time zones (Katz, 2019). 
Work from home entails a number of long-term unexplored problems, such as social distancing, selfmanagement, household dilemmas, employer dilemmas, work-life balance, being less recognized by superiors, putting sensitive information at risk, higher costs of computer devices and internet for the employee, etc. Some constraints are culture- or industry-specific. (Jewson, 2002). International research on experiences of working from home during the first year of the COVID-19 pandemic found that the top disadvantages were lack of social contacts, inability to focus, and worse work-life balance (Rubin et al., 2020).

On the other hand, working remotely increases productivity when one needs a controlled environment; it enables working flexible hours and eliminates commuting costs. Another advantage of working remotely is that enabling more freedom in choosing the mode of work in organizations as a "dual agenda" meets both organizational goals and the ability to integrate the demands of work and personal life (Rapoport, Bailyn, Fletcher \& Pruitt, 2002). A work-from-home experiment at Ctrip with 16,000 employees found a $13 \%$ increase in performance due in part to working more minutes per shift and in part to more calls per minute in a more comfortable and quiet home environment (Bloom, Liang, Roberts \& Ying, 2014). Employees also reported an improvement in job satisfaction (Bloom et al., 2014).

\subsection{Job Satisfaction}

There is no clear definition of job satisfaction. Different authors define job satisfaction differently. However, the issue is important in organizations, both today and in the past (Aziri, 2011).

Vroom (1964) defined it as a workplace that focuses on employees who are oriented to their role at work. Hoppock (1935) said that satisfaction is a combination of environmental, psychological, and physiological conditions of an individual who consequently takes pride in his or her work. It has something to do with how a person feels and what elements are the cause of satisfaction. Workers most commonly associate satisfaction with their feelings toward work. It reflects to what extent they loathe or like their jobs (Aziri, 2011). According to Davis, Leach and Clegg (1985) satisfaction is the extent to which the expectations of a worker are met in his or her position and, it is related closely to how people behave at work. Job satisfaction is in a sense success at work. Usually, it is associated with productivity and personal well-being. It means that a person enjoys doing his or her job and receives a reward for it. It suggests happiness, and can lead to fulfilment (Kaliski, 2007). It also is defined as a collection of beliefs and feelings about a person's work. It can range from extreme satisfaction to extreme dissatisfaction, and is described as an attitude toward a job.

Job satisfaction can be an essential element of efficiency and productivity of an organization. Workers should be treated morally by considering their needs, wants, and other aspects. It is said that a satisfied employee is a successful employee. When satisfaction is not present, other negative consequences occur, such as absenteeism, dissatisfaction, lack of loyalty, etc. (Dziuba, Ingaldi \& Zhuravskaya, 2020).

We assumed from previous research that positive-minded people are more satisfied with their job. Because the literature is scarce, we wanted to confirm our hypothesis. Orkibi and Brandt (2015) showed that satisfaction comes from people with positive mindset. Luthans and Youssef (2007) studied job satisfaction, and the results showed a positive correlation between hope (an element of positive capital) and job satisfaction.

H1a: Employees' positive mindset is positively related to job satisfaction.

In line with Bloom (2014) and Rapoport (2002), we assumed that working from home, when employees have a positive mindset, also contributes to higher job satisfaction through improved perception of freedom, and brings more passion to work with easier integration of work and personal life.

H1b: Mode of work moderates the positive relationship between employees' positive mindset and job satisfaction such that the basic relationship is more positive when employees work from home. 
Next, because Huang et al. (2016) suggested that more-extraverted individuals are more satisfied with jobs that demand high social interaction, we wanted to see if this could be generalized for all types of jobs, and therefore we propose the following hypothesis:

H2a: Employees' extraversion is positively related to their job satisfaction.

Due to a lack of social interaction, which extroverted employees need in order to thrive (Huang et al., 2016; Liu et al., 2021), we expect them to be less satisfied when they work from home. Therefore, we propose the following hypothesis:

H2b: Mode of work moderates the positive relationship between extraversion personality type and job satisfaction such that the basic relationship is more negative when employees work from home.

\subsection{Resilience}

Resilience is the ability to cope with shocks and continue to function in the same way. It is a measure of a society, business, or ecosystem that demonstrates the ability to change before passing a tipping point. It includes capabilities such as adaptation, change, and restructuring in coping with disruption. "It is about changing to avoid being changed" (Walker, 2020).

According to Walker (2020), nine attributes promote overall resilience: exposure to disruption; diversity of response; modularity or interconnectedness; ability to respond quickly to change or shock; readiness for transformation; thinking, planning, and managing across scales; and leading rather than directing. Therefore, exposure to variability is necessary to build and maintain resilience, whereas attempting to protect a system from shocks reduces its resilience.

On the other hand, resilience can be understood as a capacity to rebuild and recover quickly (Herbane, 2015) or as a response to a crisis (Pal, Torstensson \& Mattila, 2014). Furthermore, resilience can be seen as a characteristic that an organization possesses before, during, and after an event. Four categories of resilience in relation to time are resilience as a proactive attribute, an absorptive and adaptive attribute, a reactive attribute, or a dynamic attribute (Conz \& Magnani, 2020).
As a proactive attribute, resilience can be understood as an ability to be ready in times of crisis and maintain superior organizational performance (Pal et al., 2014). In addition, resilience as an absorptive attribute is defined as the ability to persist in the face of significant change or to withstand disruption and catastrophic events (Acquaah, AmoakoGyampah \& Jayaram, 2011). A third definition of resilience as a reactive attribute explains it as the ability to survive disruptions (McPhee, 2014).

From a dynamic perspective, resilience is conceptualized as a temporal process consisting of two pathways: adaptive and absorptive (Conz \& Magnani, 2020). The goal of resilience as a dynamic attribute is to develop multiple sources of competitive advantage (Reinmoeller \& van Baardwijk, 2005).

From a psychological perspective, there is some evidence showing a relationship between loneliness, mental health, and resilience in the era of COVID-19 (Killgore, Taylor, Cloonan \& Dailey, 2020). Child adjustment is determined in many cases by the influence of family members. Relationship quality, marital conflict, family beliefs, and communication have significant effects (especially during COVID-19) on family well-being and resilience (Prime, Wade \& Browne, 2020). We assumed that a positive mindset is positively related to resilience, because a positive mindset and resilience both are reinforced by similar factors, such as positive family beliefs and quality relationships, as discussed by Prime, Wade and Browne (2020).

H3a: Employees' positive mindset is positively related to resilience.

H3b: Mode of work moderates the positive relationship between employees' positive mindset and resilience such that the basic relationship is more positive when employees work from home.

Because less-extraverted individuals tend to have more mental health problems (Janowsky, 2001) and more adjustment problems in general (Davidson, Gillies \& Pelletier, 2015), we developed the following hypothesis:

H4a: Employees' extraversion is positively related to their resilience. 
This might be based on the suggestion that extraverted individuals show increased levels of helpseeking behavior (Kakhnovets, 2011). However, contrary to Kalinnikova et al. (2020), who showed that less-extraverted individuals tend to be more resilient when exposed to extreme stress, Wei (2020) suggested that the change of mode of work should be salient in this line of inquiry. Although this contradicts the general belief that more-extraverted individuals need social interaction to function "normally" (Lucas et al., 2008; ter Bogt, Engels \& Dubas, 2006), we decided to test Wei's (2020) assumption.

H4b: Mode of work moderates the positive relationship between the personality trait of extraversion and resilience such that the basic relationship is more positive when employees work from home.

\section{METHODOLOGY}

\subsection{Sample and collection of data}

The survey was conducted online using the 1KA web-based survey tool. The survey was distributed via Facebook, Instagram, Linkedln, and email randomly to different age groups. It was available from 18 June 2021 to 13 July 2021 . A total of 421 people started participating in our survey, of whom 230 (55\%) skipped the entry page and 161 (38\%) started answering our questions but did not finish; only 127 (30\%) surveys were completed in total. Of the 127 respondents, 81 were female and 45 were male. Most respondents $(50 \%)$ were between the ages of 18 and 24 , and the average age was 30.5 years. The education level of the respondents varied; 57 had completed high school, 39 had a bachelor's degree, 27 had a master's degree, and 2 had a professional degree. Regarding marital status, 71 respondents identified as single, 51 identified as married or cohabiting, one identified as widowed, and four identified as divorced. In terms of work status, 67 respondents were students, 53 had full-time jobs, one was retired, one was unable to work, and five were self-employed.

\subsection{Measurement}

The research questionnaire consisted of 11 sets of questions, from which one set of questions involved mindset; one involved resilience; one involved personality traits; one involved job satisfaction; one set contained four questions about work mode before, during, and after COVID-19; and another set of questions involved demographic data (including gender, age, education, marital status, employment status, monthly income, and years of work experience).

There were 10 statements in the question set measuring mindset, 10 statements measuring personality traits, six statements measuring resilience, and five statements measuring job satisfaction. With three sets of four statements, we measured the mode of work (i.e., office/physical location, hybrid system as rotation, hybrid system as working at the preferable destination, and work from home) before and during COVID-19, and the preferred mode of work in the future.

All the measuring scales were validated and checked beforehand, but for easier analysis, we converted the measuring scale from 5-point to 7-point Likert scales. In the quantitative part of the survey, each item was rated on a 7-point Likert scale from 1 for "strongly disagree" to 7 for "strongly agree."

Scheier, Carver, and Bridges' (1994) 10-item scale (Cronbach's alpha $=0.546$ ) was used to measure perceived mentality. Personality traits were measured using the 10 -item scale (Cronbach's alpha $=0.899)$ by Topolewska-Siedzik (2014). Job satisfaction was measured using the five-item scale (Cronbach's alpha = 0.905). To measure resilience, we used the Brief Resilience Scale (BRS) (Cronbach's alpha $=0.758$ ), which consists of six items and was developed by Smith, Dalen, Tooley, Christopher and Bernard (2008).

To analyze the respondents' work practises, we asked three questions about their primary work practises before COVID-19 and after COVID-19, and their preferred work practises in the future. For each of the three questions, there were four response options: office/physical location, hybrid - rotation, hybrid (being able to choose to work from home or in the office), and from home/remote.

\subsection{Research Model}

In our research model, we hypothesized that job satisfaction and resilience can be predicted by mindset and personality traits. We assumed that the relationship between the variables is moderated by the conditional variable "mode of work." 
Figure 1: Research model with hypotheses

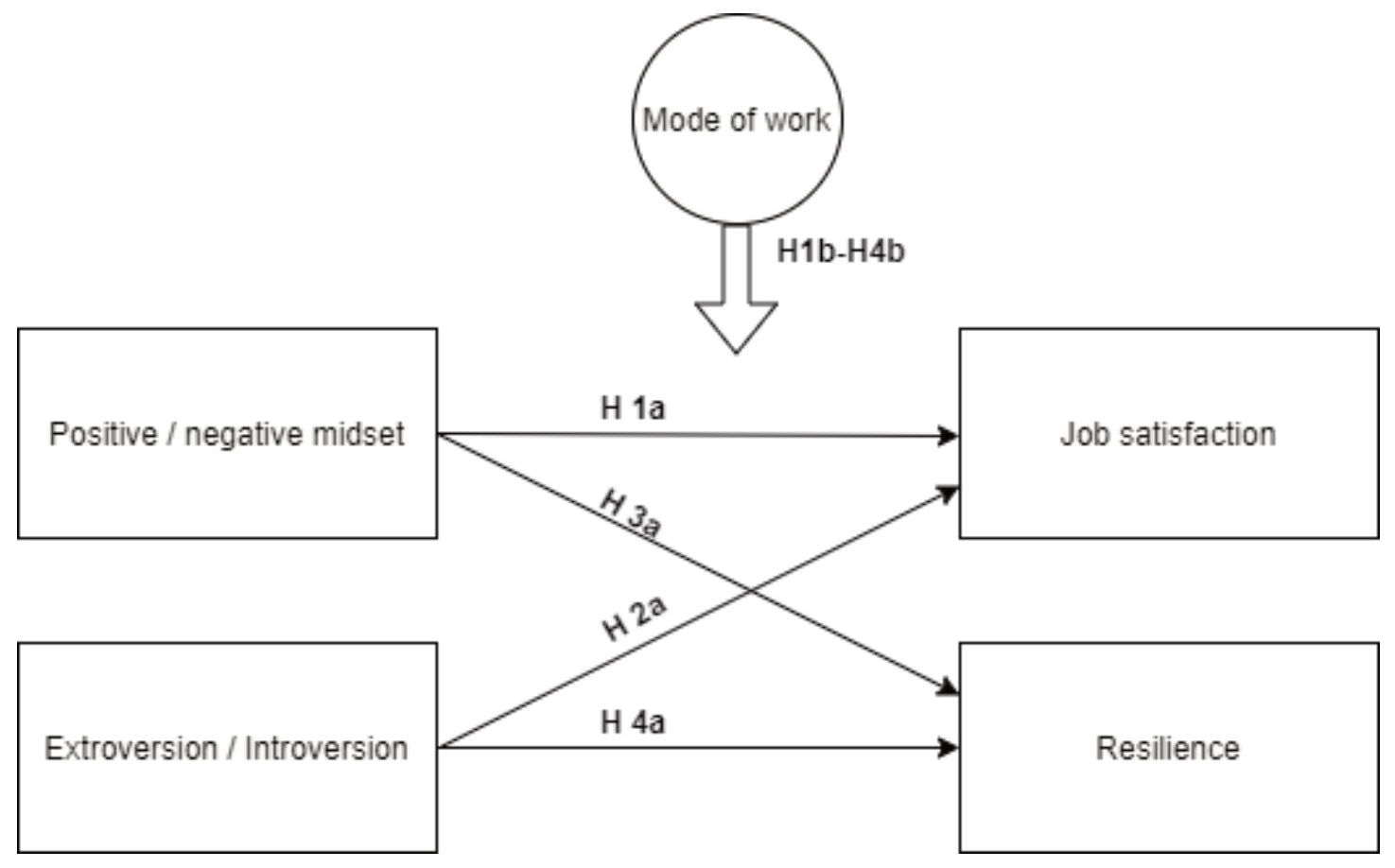

\subsection{Procedure}

To obtain an overview of the data, we first performed a descriptive analysis, obtaining the means, standard deviations (SDs), and Pearson correlation coefficients of our main variables. Then we conducted a multiple linear regression analysis to examine the relationships between extraversion and resilience, mindset and resilience, extraversion and job satisfaction, and mindset and job satisfaction. In addition, we conducted moderated regression using Model 1 in PROCESS macro version 3 (Hayes, 2018) to examine the moderating effect of mode of work on the basic association between the observed variables.

\section{RESULTS}

Through descriptive analysis in SPSS, we obtained the following data (Tables 1 and 2). From 148 valid answers $(N=148)$ we obtained a general idea about the individuals' mindsets, indicating that our participants had, on average, more positive mindsets $(M=4.4572)$. Standard deviations showed that all data were quite clustered (SD $=0.77789)$.
For our measurement of extraversion, the number of valid answers decreased $(N=145)$. The mean score was approximately in the middle of the extraversion spectrum $(M=4.1869)$, yet the standard deviation was quite high, as expected, because people are different in terms of their extraversion (SD = 1.20521).

In terms of job satisfaction, our participants $(N=132)$ were more on the satisfied side $(M=$ 5.3924$, SD $=1.06216)$. Finally, for our last measured trait, resilience, which also had the fewest valid answers $(N=128)$, the scoring was about average for our group of participants $(M=4.3346$, SD $=0.97149$ ).

Most respondents $(32.3 \% ; N=127)$ said that before COVID-19 they mostly worked from the office/physical location, and during the COVID-19 crisis, this percentage increased to $42 \%$. Furthermore, $35 \%$ said their mode of work had not changed and that they liked it, but for future preferences, most participants said that they would prefer to work from the office/physical location again. 
Table 1: Descriptive statistics

\begin{tabular}{|c|c|c|c|c|c|c|c|c|c|}
\hline & \multirow[b]{2}{*}{$N$} & \multirow[b]{2}{*}{ Minimum } & \multirow[b]{2}{*}{ Maximum } & \multirow[b]{2}{*}{ Mean } & \multirow{2}{*}{$\begin{array}{l}\text { Standard } \\
\text { deviation }\end{array}$} & \multicolumn{2}{|c|}{ Skewness } & \multicolumn{2}{|c|}{ Kurtosis } \\
\hline & & & & & & Statistic & $\begin{array}{l}\text { Standard } \\
\text { error }\end{array}$ & Statistic & $\begin{array}{c}\text { Standard } \\
\text { error }\end{array}$ \\
\hline Age & 127 & 2 & 5 & 3.02 & 1.198 & 0.685 & 0.215 & -1.141 & 0.427 \\
\hline Employment & 127 & 1 & 7 & 1.70 & 1.143 & 2.911 & 0.215 & 9.330 & 0.427 \\
\hline Income & 127 & 1 & 6 & 3.16 & 1.883 & 0.167 & 0.215 & -1.455 & 0.427 \\
\hline Job satisfaction mean & 132 & 1.00 & 7.00 & 5.3924 & 1.06216 & -1.453 & 0.211 & 3.603 & 0.419 \\
\hline Mindset mean & 148 & 2.00 & 6.00 & 4.4572 & .77789 & -0.602 & 0.199 & 0.838 & 0.396 \\
\hline Personality mean & 145 & 1.00 & 6.80 & 4.1869 & 1.20521 & -0.219 & 0.201 & -0.330 & 0.400 \\
\hline Resilience mean & 128 & 1.00 & 6.67 & 4.3346 & .97149 & -0.246 & 0.214 & 1.288 & 0.425 \\
\hline Work mode before & 127 & 1 & 4 & 1.45 & .906 & 1.846 & 0.215 & 2.032 & 0.427 \\
\hline $\begin{array}{l}\text { Work mode change } \\
\text { satisfaction }\end{array}$ & 127 & 1 & 4 & 2.13 & .920 & 0.102 & 0.215 & -1.168 & 0.427 \\
\hline Work mode during & 127 & 1 & 4 & 2.65 & 1.313 & -0.195 & 0.215 & -1.721 & 0.427 \\
\hline Work mode wish & 127 & 1 & 4 & 2.09 & .968 & 0.251 & 0.215 & -1.177 & 0.427 \\
\hline Valid N (listwise) & 127 & & & & & & & & \\
\hline
\end{tabular}

Table 2: Symmetry measures

\begin{tabular}{|l|c|c|c|c|c|c|}
\hline \multicolumn{2}{|c|}{} & $\begin{array}{c}\text { Personality } \\
\text { mean }\end{array}$ & $\begin{array}{c}\text { Job satisfaction } \\
\text { mean }\end{array}$ & $\begin{array}{c}\text { Resilience } \\
\text { mean }\end{array}$ & $\begin{array}{c}\text { Mindset } \\
\text { mean }\end{array}$ & $\begin{array}{c}\text { Work mode } \\
\text { during }\end{array}$ \\
\hline \multirow{2}{*}{$N$} & Valid & 145 & 132 & 128 & 148 & 127 \\
\cline { 2 - 7 } & Missing & 16 & 29 & 33 & -.602 & -.195 \\
\hline Skewness & -.219 & -1.1453 & -.246 & .199 & .215 \\
\hline Standard error of skewness & .201 & .211 & .214 & .838 & -1.721 \\
\hline Kurtosis & -.330 & 3.603 & 1.288 & .396 & .727 \\
\hline Standard error of kurtosis & .400 & .419 & .425 & 4.00 & 3 \\
\hline Range & 5.80 & 6.00 & 5.67 & & \\
\hline
\end{tabular}

In the next step, linear regression was conducted. The results are summarized in Table 3. Model 1 had mindset as a predictor and job satisfaction as the dependent variable), and Model 2 had personality as pre- dictor and job satisfaction as the dependent variable. In Model 3, mindset was the predictor and resilience was the dependent variable. In Model 4, personality was the predictor and resilience was the dependent variable.

Table 3: Linear regression results

\begin{tabular}{|l|c|c|c|c|c|}
\hline Model & $\boldsymbol{R}$ & $\boldsymbol{R}^{\mathbf{2}}$ & $\boldsymbol{F}$ & $\boldsymbol{B}$-value & $\boldsymbol{p}$-value \\
\hline Model 1 & 0.364 & 0.133 & 19.888 & 0.481 & 0.000 \\
\hline Model 2 & 0.310 & 0.096 & 13.842 & 0.272 & 0.000 \\
\hline Model 3 & 0.455 & 0.207 & 32.902 & 0.545 & 0.000 \\
\hline Model 4 & 0.412 & 0.170 & 25.803 & 0.329 & 0.000 \\
\hline
\end{tabular}


To test Hypothesis $\mathrm{H} 1 \mathrm{a}$, Model 1 with mindset as predictor and job satisfaction as the dependent variable had an $R$-value of 0.364 and $R^{2}=0.133$. Therefore, $13.3 \%$ of variation in job satisfaction could be explained by variation in mindset. However, the $p$-value, which meanes statistical significance, was 0.000 . Hence, we can accept our hypothesis that employees' positive mindset is positively related to job satisfaction, and with a $1 \%$ increase in the mindset score, we would expect a $0.481 \%$ increase in job satisfaction.

In Model 2, testing the H2a hypothesis, with personality as the predictor and job satisfaction as the dependent variable, the $R$-value was 0.310 and $R^{2}=$ 0.096 , meaning that only $9.6 \%$ of variation in job satisfaction could be explained by variation in the personality trait of extraversion. A $p$-value of 0.000 indicated statistical significance, and therefore with $1 \%$ increase in the personality trait of extraversion, we would expect a $0.272 \%$ increase in job satisfaction. Therefore we can accept our hypothesis that employees who are more extraverted are more satisfied with their job than those who are less extraverted.

Model 3, which tested Hypothesis $\mathrm{H3a}$, had an $R$-value of 0.455 and $R^{2}=0.207$, meaning that $20.7 \%$ of variation in resilience can be explained by a variation in mindset. The $p$-value was 0.000 , which means that there is a connection between mindset and resilience, and we can accept our hypothesis and say that employees' positive mindset is positively related to resilience. Based on our results, with a $1 \%$ increase in an individual's mindset, we can expect a $0.545 \%$ increase in the resilience score.

There appears to be a connection between the personality trait of extraversion and resilience as we predicted with Hypothesis $\mathrm{H} 4 \mathrm{a}$ and as described in Model 4 . The $R$-value for Model 4 was 0.412 and $R^{2}$ $=0.170$, meaning that $17.0 \%$ of variation in re- silience can be explained by variation of personality trait of extraversion. The $p$-value was 0.000 , so we can accept our hypothesis that employees who are more extraverted are more resilient than the ones who are less extraverted. With a $1 \%$ increase in the personality trait of extraversion, we would expect a $0.329 \%$ increase in the resilience score.

Finally, the results of the analysis with the PROCESS macro modelling tool (Hayes, 2018) in SPSS are reported in Table 4. With mode of work during the COVID-19 lockdown set as a moderator, regressions were run. Model 1 had mindset as the independent variable and job satisfaction as the dependent variable, and in Model 2 the dependent variable was job satisfaction and the independent was the individual's personality traits (extraversion). In Model 3, the dependent variable was changed to resilience and the observed independent variable was mindset. In Model 4, personality trait (extraversion) was the independent variable and the dependent variable was resilience.

In our first hypothesis, we predicted that mode of work moderates the relationship between mindset and job satisfaction ( $\mathrm{H} 1 \mathrm{~b})$. The $p$-value for Model 1 (mindset and job satisfaction) was 0.2351 , so we can reject Hypothesis $\mathrm{H} 1 \mathrm{~b}$ and say that mode of work does not moderate the positive relationship between employees' positive mindset and job satisfaction such that the basic relationship is more positive when employees work from home.

Next, we tested whether mode of work moderates the relationship between extraversion and job satisfaction ( $\mathrm{H} 2 \mathrm{~b}$ ). Model 2 (personality trait and job satisfaction) had a $p$-value of 0.5225 , so we reject Hypothesis $\mathrm{H} 2 \mathrm{~b}$ that mode of work moderates the positive relationship between extraversion personality type and job satisfaction such that the basic relationship is more negative when employees work from home.

Table 4: Moderated linear regression

\begin{tabular}{|l|c|c|c|c|c|}
\hline Model & $\boldsymbol{R}$ & $\boldsymbol{R}^{\mathbf{2}}$ & $\boldsymbol{F}$ & $\boldsymbol{B}$-value & $\boldsymbol{p}$-value \\
\hline Model 1 & 0.3804 & 0.1447 & 6.931 & 0.364 & 0.2351 \\
\hline Model 2 & 0.3206 & 0.1028 & 4.6978 & 0.310 & 0.5225 \\
\hline Model 3 & 0.5536 & 0.3065 & 18.1192 & 0.455 & 0.0021 \\
\hline Model 4 & 0.4940 & 0.2440 & 13.2337 & 0.412 & 0.1534 \\
\hline
\end{tabular}


Our third hypothesis ( $\mathrm{H} 3 \mathrm{~b})$ tested whether mode of work moderates the relationship between mindset and resilience. Model 3, with mindset as the independent variable and resilience as the dependent variable, indicated statistically significant results, with a $p$-value of 0.0021 . The $R^{2}$ value indicates that about $30.65 \%$ of the variability in resilience can be explained by changes in mindset. Therefore, we can accept our hypotheses that an employee's positive mindset is positively related to resilience and that mode of work moderates the positive relationship between employees' positive mindset and resilience such that the basic relationship is more positive when employees work from home.

The fourth moderator hypothesis (H4b), Model 4 , with personality traits (extraversion) as the independent variable and resilience as the dependent variable, had the second best significance, with a $p$ value of 0.1534 . The $R^{2}$ value indicates that extraversion could be accountable for $24.40 \%$ of the variability in resilience. Still, we have to reject the hypothesis that mode of work moderates the positive relationship between personality trait of extraversion and resilience.

\section{DISCUSSION AND CONCLUSION}

\subsection{Interpretation of Findings}

We systematically approached our goal and used different methods of research to determine if there are any existing connections between the individual characteristics (personality trait of extraversion and positive mindset) of employees and their job satisfaction and resilience. We also determined if mode of work as a moderator had any impact on those connections. Based on the obtained results, we can draw some conclusions. The descriptive statistics indicate that our sample was quite representative in terms of mean scores for each observed variable. Job satisfaction varies between countries-it is highest in India (79\%) and lowest in Japan (42\%); the value for Europe is about 73\% (Randstad, 2021). The number of participants who had a mean score of five or higher indicates that $75 \%$ of them appear to be satisfied with their jobs. This again suggests that our sample is representative. Furthermore, 73 participants also scored above the mean in extraversion, which represents an approximate middle of the extraversion scale spectrum; we could say that approximately $61 \%$ of participants can be classified as extraverts. This agrees with the general approximation that extraverts make up $50 \%-74 \%$ of the population (Buettner, 2012). Therefore, we can say that our sample is representative because the percentage of extraverts appears to be similar to that in real life.

Linear regression confirmed all our hypotheses and the existing connections between the observed variables. The strongest connections were between the individual's mindset and resilience $\left(R^{2}=0.207\right)$ and between the personality trait of extraversion and resilience $\left(R^{2}=0.170\right)$. However, PROCESS macro modelling using mode of work during COVID-19 as a moderator confirmed only the hypothesis that employees' positive mindset is positively related to resilience and that mode of work moderates the positive relationship between employees' positive mindset and resilience such that the basic relationship is more positive when employees work from home. Mode of work during COVID-19 was chosen because we were measuring job satisfaction, which is a dynamic parameter and is very situation-dependent. Therefore we had to use the current situation to obtain the best results. All the other hypotheses with mode of work during COVID-19 set as moderator were rejected. We found existing connections between observed variables. There appear to be stronger connections between mindset, extraversion and resilience, whereas job satisfaction was not connected strongly to any of those variables.

\subsection{Theoretical Contributions}

Our research provides some theoretical contributions in the field of extraversion and its effect on job satisfaction and resilience. We found that a weak connection between extraversion and job satisfaction. This means that other factors have more impact on job satisfaction, and, theoretically, a very introverted and a very extraverted individual could be equally satisfied with their jobs regardless of their mode of work. Because no significant connection was found between job satisfaction and extraversion with mode of work as moderator, we advance and contrast the findings of Huang et al. 
(2016) by showing that more-extraverted individuals need more stimulation to be satisfied with their jobs. We confirmed the hypothesis that more-extraverted individuals tend to be more resilient than those who are less extraverted and we. We also reinforced what the has literature already suggested, that there is a strong connection between mindset and resilience. Our research also helps to fill the gap about the connections between mindset and job satisfaction, which was very scarce; we showed that there in fact is a weak connection.

\subsection{Practical Contributions}

As a practical contribution, we can say that managers need to encourage their employees to build a positive mindset, because this seems to strengthen the resilience we need in times of crisis. Furthermore, we rejected the hypothesis that mode of work moderates the positive relationship between extraversion personality type and job satisfaction, which means that actions regarding returning to the office after the COVID-19 epidemic has passed (or at least calmed down) require a more individualized approach than was thought. Therefore, managers will need to consult with their employees to make decisions, because our research found that less-extraverted individuals are not necessarily more likely to want to work from home.

\subsection{Limitations}

The first problem with the questionnaire we used was that it was too long, so our completion rate was very low. To improve this, we should have created a separate questionnaire from another research group to make it shorter, which probably would have given us a larger sample and thus a better insight into the phenomenon. In addition, we should have worded some of the questions better and added some additional questions to avoid possible bias and to determine whether other variables could have an impact on our research subjects. For example, we could ask participants if they recently have been exposed to very stressful events (e.g., the death of a relative, illness, failing a course, being fired, etc.). If so, this could be a factor affecting resilience, and we might therefore expect to see a change in resilience scores. Furthermore, the timing of our survey could have been better. Because we conducted the survey just before the summer holidays, we could have expected that some of the employees might have been annoyed and not interested in our survey, or that their answers might have been biased. For example, if their boss gave them a bonus just before the holidays, they may have been more likely to say that they currently were very satisfied with their job than if they were surveyed at another time. The sampling method we used was not random; opportunity sampling was used, which had an effect on our sample, as is evident from the demographic information. Many of the participants were in the same age group as the researchers, and many of them said that they were still full-time students, which was not ideal for measuring job satisfaction, because they did not have experience or their experience was limited. From this perspective, we could improve our research by sending our survey directly to large companies, which would distribute it to their employees. Of course, we would have to be careful to include as many different industries as possible and determine if there are any differences between them.

\subsection{Future Research}

Our research raises some questions and points to some areas and issues that could be explored further. One possible issue is the impact of ambition on job satisfaction. Some research suggests that extraverts are more likely to respond to rewards than are introverts (Ashton, Lee \& Paunonen, 2002; Lucas \& Diener, 2000), which could mean that extraverts currently are more frustrated, because climbing the social ladder is seen as a reward. It would be interesting to test whether there is a correlation between individuals' personality traits and their ambitions in terms of how they respond to working from home and how it affects their job satisfaction. Next, we also could investigate whether the tasks that participants have to complete at their workplace correlate with their satisfaction. Previous research has shown that tasks that do not match personality traits and personal preferences can cause irritability, boredom, anxiety, and dissatisfaction (Edwards \& Harrison 1993; Kristoff-Brown et al., 2005). The displacement 
of these tasks as a result of the epidemic could lead to individuals being less satisfied with their jobs. Furthermore, we could determine whether certain areas are preferred by employees with different personality traits. In conducting this type of research, we also could examine the design of office spaces, because different people have different preferences for their workspace (Davis et al., 2011). Because introverts are more easily overstimulated by the environment, it would be interesting to see if the design of their current workspace affects their job satisfaction. Based on recent studies, we also could study whether less-extraverted people find the current form of remote work more satisfying than those who are more extraverted. In addition, current employer preferences and their impact on employee job satisfaction could be explored further. Aziz and Pangil (2017) found that individuals who are more extraverted and therefore "better at selling themselves" (Kristof-Brown et al., 2002) are more likely to be hired than are their introverted counterparts; however, some studies suggest that introverts may outperform their extraverted counterparts in making risky decisions, yet they often are overlooked (Kuhnen \& Chiao, 2009). Lastly, the aspect of resilience also could be included here, because introverted employees often feel excluded and overlooked (McCord \& Joseph, 2020). Research here could include both perspectives - that of the employer, and that of the employee. We could study how well introverted employees perform under stress (taking safety precautions into account) and how they behave after making mistakes. This could be interesting, because Brebner and Cooper (1978) found that extraverts become faster after making a mistake, whereas introverts tend to pause and examine what happened to avoid making the same mistake in the future. Especially in times of uncertainty brought about by the pandemic, it would be interesting to observe how individuals with different personality traits deal with risk and how the mistakes they make affect their job satisfaction.

\section{EXTENDED SUMMARY/IZVLEČEK}

Organizacije so v času pandemije COVID-19 iskale nove načine, kako prilagoditi ureditev dela in vpeljati različne pojavne oblike dela (npr. hibridno delo, delo na daljavo) ter ob tem ohraniti zadovoljstvo svojih zaposlenih. Ta članek je raziskal razmerje med osebnostnimi karakteristikami zaposlenih in njihovimi vplivi na trdoživost zaposlenih in zadovoljstvo pri delu. Študija je prav tako raziskala ali se ta razmerja razlikujejo $\mathrm{v}$ različnih pojavnih oblikah dela. Izsledki raziskave so pomembni za managerje, saj jim pomagajo razumeti povezavo med individualnimi karakteristikami zaposlenih in rezultati pri delu v okviru določene pojavne oblike dela.

\section{REFERENCES}

Acquaah, M., Amoako-Gyampah, K. \& Jayaram, J. (2011). Resilience in family and nonfamily firms: an examination of the relationships between manufacturing strategy, competitive strategy and firm performance. International Journal of Production Research, 49, 18, 5527-5544.

Adigun, A. O., Oyekunle, I. A. \& Onifade, T. (2017). Influence of job satisfaction on employees' performance in MTN Nigeria. Global Journal of Human Resource Management, 5(5), 54-60.
Ashton, M. C., Lee, K. \& Paunonen, S. V. (2002). What is the central feature of extraversion? Social attention versus reward sensitivity. Journal of personality and social psychology, 83(1), 245.

Aziri, B. (2011). Job satisfaction: a literature review. Management Research \& Practice, 3(4).

Aziz, A. \& Pangil, F. (2017). Moderating Effect of Emotional Intelligence on the Relationship between Personality Traits and Employability. Saudi Journal of Humanities and Social Sciences, 2(2), 132-139.

Bloom, N., Liang, J., Roberts, J. \& Ying, Z. (2014). Does Working from Home Work? Evidence from a Chinese 
Janina Gašperlin, Nuša Dovžan, Karmen Ferjan, Amadeja Lamovšek : The Interaction Between Individual Characteristics and Mode of Work in Predicting Resilience and Job Satisfaction

Experiment. The Quarterly Journal Of Economics, 130(1), 165-218.

Bloom, N., Liang, J., Roberts, J. \& Ying, Z. J. (2015). Does working from home work? Evidence from a Chinese experiment. The Quarterly Journal of Economics, 130(1), 165-218.

Brebner, J. \& Cooper, C. (1978). Stimulus-or response-induced excitation. A comparison of the behavior of introverts and extraverts. Journal of Research in Personality, 12(3), 306-311.

Buettner, D. (2012). Are Extroverts Happier Than Introverts? Retrieved July 2021, from https://www.psychologytoday.com/us/blog/thrive/201205/are-extrov erts-happier-introverts

Cain, S. (2012). Quiet: The power of introverts in a world that can't stop talking. Crown Publishers/Random House.

Carver, C. S. \& Scheier, M. F. (1998). On the self-regulation of behaviour. Cambridge University Press. New York, NY, US.

Carver, C. S., Scheier, M. F. \& Segerstrom, S. C. (2010). Optimism. Clinical psychology review, 30(7), 879-889.

Cavus, M. F. \& Gokcen, A. (2015). Psychological capital: Definition, components and effects. Journal of Education, Society and Behavioural Science, 244-255.

Conklin, E.S. (1923). The definition of Introversion, Extroversion and Allied Concepts. Journal of Abnormal Psychology and Social Psychology, 17, 367-382

Conz, E. \& Magnani, M. (2020). A dynamic perspective on the resilience of firms: A systematic literature review and a framework for future research. European Management Journal, 38,(3), 400-412.

Davidson, B., Gillies, R. \& Pelletier, A. (2015). Introversion and Medical Student Education: Challenges for Both Students and Educators. Teaching And Learning In Medicine, 27(1), 99-104.

Davis, K. and Nestrom, J.W. (1985). Human Behavior at work: Organizational Behavior, 7th edition. McGraw Hill, New York, p.109

Davis, M. C., Leach, D. J. \& Clegg, C. W. (2011). The Physical Environment of the Office: Contemporary and Emerging Issues. In G. P. Hodgkinson \& J. K. Ford (Eds.), International Review of Industrial and Organizational Psychology (Vol. 26, pp. 193 - 235). Chichester, UK: Wiley.

Digman, J. (1990). Personality Structure: Emergence of the Five-Factor Model. Annual Review Of Psychology, 41(1), 417-440.

Dweck CS. (2007). Mindset: The New Psychology of Success. Updated Edition. Ballantine Books.

Dziuba, S. T., Ingaldi, M. \& Zhuravskaya, M. (2020). Employees' job satisfaction and their work performance as elements influencing work safety. System Safety: Human-Technical Facility-Environment, 2(1).
Edwards, J. R., \& Van Harrison, R. (1993). Job demands and worker health: Three-dimensional reexamination of the relationship between person-environment fit and strain. Journal of Applied Psychology, 78(4), 628-648.

Employers' Federation of India. (2020). Work from home. A policy prescription. ILO.

Fuller, H. R. \& Huseth-Zosel, A. (2021). Lessons in Resilience: Initial Coping Among Older Adults During the COVID-19 Pandemic. The Gerontologist, 61(1), 114-125.

Gensowski, M. (2018). Personality, IQ, and lifetime earnings. Labour Economics, 51, 170-183.

George, J. M., \& Jones, G. R. (2005). Understanding and managing organizational behavior. Upper Saddle River, N.J: Pearson Prentice Hall.

Gilrane, V. (2019). Working together when we're not together. Google. Retrieved August $1^{\text {st }}$ from: https://blog.google/inside-google/life-at-google/working-together-when-were-not-together/.

Goby, V. P. (2006). Personality and online/offline choices: MBTI profiles and favored communication modes in a Singapore study. Cyberpsychology \& behavior, 9(1), 5-13.

Hayes, A. F. (2018). Introduction to mediation, moderation, and conditional process analysis: A regressionbased approach (2nd ed.). New York: The Guilford Press.

Herbane, B. (2015). Threat orientation in small and medium-sized enterprises: understandingdifferences toward acute interruptions. Disaster Prevention and Management, 24(5), 583-595.

Hill, E., Ferris, M. \& Märtinson, V. (2003). Does it matter where you work? A comparison of how three work venues (traditional office, virtual office, and home office) influence aspects of work and personal/family life. Journal Of Vocational Behavior, 63(2), 220-241.

Hobfoll, S. E. (2011). Conservation of resources theory: Its implication for stress, health, and resilience. In S. Folkman (Ed.), The Oxford handbook of stress, health, and coping (pp. 127-147). Oxford University Press.

Hoppock, R. (1935). Job Satisfaction. Harper and Brothers, New York, p. 47

Houston, E. (2021). Introvert vs Extrovert: A Look at the Spectrum and Psychology. Retrieved 10 August 2021, from https://positivepsychology.com/introversion-extroversion-spectrum/

Huang, J. L., Bramble, R. J., Liu, M., Aqwa, J. J., Ott-Holland, C. J., Ryan, A. M., ... \& Wadlington, P. L. (2016). Rethinking the association between extraversion and job satisfaction: The role of interpersonal job context. Journal of Occupational and Organizational Psychology, 89(3), 683-691.

Janowsky, D.S. (2001). Introversion and extroversion: Implications for depression and suicidality. Curr Psychiatry Rep, 3, 444-450. 
Jewson, N. (2002). In Work, At Home: Towards an Understanding of Homeworking. Routledge.

Jung, C. G. (1921). Psychological Types. The Collected Works of C. G. Jung, Vol. 6, Bollingen Series XX.

Kakhnovets, R. (2011). Relationships among personality, expectations about counseling, and help-seeking attitudes. Journal of Counseling \& Development, 89(1), 11-19.

Kalinnikova, L., Zavodilov, A. \& Dmitrijeva, O. (2020). Stress Symptoms under Extreme Circumstances in Latvian National guard Personnel with different Personality Supertraits.

Kaliski, B.S. (2007). Encyclopedia of Business and Finance. Thompson Gale, Detroit, p. 446

Katz, G. (2019). Future of work: What Google learned about remote work from its employees. Retrieved August 14, 2021 from https://www.theladders.com/career-advice/what-google-learned-about-remote-work -from-its-employees.

Kempf Taylor, Melissa. (2020). Personality Styles: Why They Matter in the Workplace. 10.37075/EA.2020.1.08.

Killgore, W. D. S., Taylor, E. C., Cloonan, S. A. \& Dailey, N. S. (2020). Psychological resilience during the covid-19 lockdown. Psychiatry Research, 291, 113216.

Kristof-Brown, A., Barrick, M. \& Franke, M. (2002). Applicant Impression Management: Dispositional Influences and Consequences for Recruiter Perceptions of Fit and Similarity. Journal Of Management, 28(1), 27-46.

Kristoff-Brown, A., R. Zimmerman, E. Johnson. (2005). Consequences of individual's fit at work: A meta-analysis of person-job, person-organization, person-group, and person-supervisor fit. Personnel Psychology, 58(2), 281-342

Kuhnen, C. \& Chiao, J. (2009). Genetic Determinants of Financial Risk Taking. Plos ONE, 4(2), e4362.

Liu, S., Lithopoulos, A., Zhang, C., Garcia-Barrera, M. \& Rhodes, R. (2021). Personality and perceived stress during COVID-19 pandemic: Testing the mediating role of perceived threat and efficacy. Personality And Individual Differences, 168, 110351.

Lounsbury, J. W., Moffitt, L., Gibson, L. W., Drost, A. W., \& Stevens, M. (2007). An Investigation of Personality Traits in Relation to Job and Career Satisfaction of Information Technology Professionals. Journal of Information Technology, 22(2), 174-183.

Lucas, R. E., Le, K. \& Dyrenforth, P. S. (2008). Explaining the extraversion/positive affect relation: Sociability cannot account for extraverts' greater happiness. Journal of personality, 76(3), 385-414.

Luthans, F., Vogelgesang, G. R. \& Lester, P. B. (2006). Developing the Psychological Capital of Resiliency. Human Resource Development Review, 5(1), 25-44.

McCord, M. \& Joseph, D. (2020). A framework of negative responses to introversion at work. Personality And Individual Differences, 161.
McPhee, W. (2014). A new sustainability model: Engaging the entire firm. Journal of Business Strategy, 35(2), 4-12

Mullins, L. J. (2005). Management and organisational behaviour. Harlow, England: Prentice Hall/Financial Times.

Nilles, J.M. (1998). Managing Telework: Strategies for Managing the Virtual Workforce. New York: John Wiley \& Sons.

Noopur, R. B. (2021). Role of perceived HRM toward workplace bullying and turnover intention: mediating role of resilience and psychological health. Asia-Pacific Journal of Business Administration.

Orkibi, H. \& Brandt, Y. I. (2015). How positivity links with job satisfaction: Preliminary findings on the mediating role of work-life balance. Europe's journal of psychology, 11(3), 406.

Pal, R., Torstensson, H. \& Mattila, H. (2014). Antecedents of organizational resilience in economic crises-an empirical study of Swedish textile and clothing SMEs. International Journal of Production Economics, 147, 410-428.

Prime, H., Wade, M., Browne, D., T. (2020). Risk and Resilience in Family Well-Being During the COVID-19 Pandemic. American Psychologist, 75, 631-643.

Randstad Workmonitor (2021). Q4 2019 report. Retrieved 1 August 2021, from https://workforceinsights.randstad.com/hr-research-reports-workmonitor-q42019

Rapoport, R. Bailyn, L. Fletcher, J. \& Pruitt, B. (2002). Beyond Work-Family Balance. Advancing Gender Equity and Workplace Performance. London: Wiley.

Reinmoeller, P. \& van Baardwijk, N. (2005). The link between diversity and resilience. MIT Sloan Management Review, 46(4), 61.

Rhinesmith, S. H. (1992). Global mindsets for global managers. Training \& Development, 46(10).

Richard E. Lucas \& Ed Diener (2000).Cross-Cultural Evidence for the Fundamental Features of Extraversion. Journal of Personality and Social Psychology, 79(3), 452-68.

Roccas, S., Sagiv, L., Schwartz, S. \& Knafo, A. (2002). The Big Five Personality Factors and Personal Values. Personality And Social Psychology Bulletin, 28(6), 789801. doi: 10.1177/0146167202289008

Rubin, O., Nikolaeva, A., Nello-Deakin, S. \& te Brömmelstroet, M. (2020). What can we learn from the COVID19 pandemic about how people experience working from home and commuting. Centre for Urban Studies, University of Amsterdam.

Sagiv, L. \& Schwartz, S.H. (2007). Cultural values in organizations: insights for Europe. European Journal of International Management, 1(3), 176-190.

Sagone, E. \& Caroli, M. E. (2015). Positive personality as a predictor of high resilience in adolescence. Journal of Psychology and Behavioral Science, 3(2), 45-53. 
Janina Gašperlin, Nuša Dovžan, Karmen Ferjan, Amadeja Lamovšek : The Interaction Between Individual Characteristics and Mode of Work in Predicting Resilience and Job Satisfaction

Sagone, E. \& Caroli, M. E. (2015). Positive personality as a predictor of high resilience in adolescence. Journal of Psychology and Behavioral Science, 3(2), 45-53.

Saltiel, F. (2020). Who can work from home in developing countries? Covid Economics, 7, 104-118.

Sanchez-Roige, S., Gray, J., MacKillop, J., Chen, C. \& Palmer, A. (2017). The genetics of human personality. Genes, Brain and Behavior, 17(3), e12439.

Scheier, M. F., \& Carver, C. S. (2003). Self-regulatory processes and responses to health threats: Effects of optimism on well-being. In J. Suls \& K. A. Wallston (Eds.), Social psychological foundations of health and illness (pp. 395-428). Blackwell Publishing.

Scheier, M. F., Carver, C. S., \& Bridges, M. W. (1994). Distinguishing optimism from neuroticism (and trait anxiety, self-mastery, and self-esteem): A re-evaluation of the Life Orientation Test. Journal of Personality and Social Psychology, 67, 1063-1078.

Shokrkon, A. \& Nicoladis, E. (2021). How personality traits of neuroticism and extroversion predict the effects of the COVID-19 on the mental health of Canadians. Plos one, 16(5), e0251097.

Smith, B. W., Dalen, J., Wiggins, K., Tooley, E., Christopher, P. \& Bernard, J. (2008). The Brief Resilience Scale: Assessing the ability to bounce back. International Journal of Behavioral Medicine, 15(3), 194-200.

Soto, C. J., Kronauer, A. \& Liang, J. K. (2016). Five-factor model of personality. In S. K. Whitbourne (Ed.), Encyclopedia of adulthood and aging (Vol. 2, pp. 506-510). Hoboken, NJ: Wiley.

Staker, H., B. Horn, M. (2012). Classifying K-12 Blended Learning. Innosight Institute.

Stewart, G. L., Dustin, S. L., Barrick, M. R. \& Darnold, T. C. (2008). Exploring the handshake in employment interviews. Journal of Applied Psychology, 93(5), 11391146 .

ter Bogt, T.F.M., Engels, R.C.M.E. \& Dubas, J.S. (2006).. Party people: Personality and MDMA use of house partyvisitors. Addictive Behaviors, 31, 1240-1244.

Tenney, E. R., Logg, J. M. \& Moore, D. A. (2015). (Too) optimistic about optimism: The belief that optimism improves performance. Journal of personality and social psychology, 108(3), 377.

Topolewska-Siedzik, E., Skimina, E., Strus, W., Cieciuch, J. \& Rowiński, T. (2014). The short IPIP-BFM-20 questionnaire for measuring the big five. Roczniki Psychologiczne, 17(2), 367-384.

Vinkers, C. H., van Amelsvoort, T., Bisson, J. I., Branchi, I., Cryan, J. F., Domschke, K., Howes, O. D., Manchia, M., Pinto, L., de Quervain, D., Schmidt, M. V. \& van der Wee, N. J. A. (2020). Stress resilience during the coronavirus pandemic. European Neuropsychopharmacology, 35, 12-16.
Vroom, V.H. (1964). Work and motivation. New York: John Wiley \& Sons.

Walker, B. H. (2020). Resilience: what it is and what is not. Ecology and Society, 25.

Walne, M. B. (2012). Emerging Blended-Learning Models and School Profiles. EduStart LLC.

Wei, M. (2020). Social Distancing and Lockdown - An Introvert's Paradise? An Empirical Investigation on the Association Between Introversion and the Psychological Impact of COVID19-Related Circumstantial Changes. Frontiers In Psychology, 11.

Wijngaards, I., Sisouw de Zilwa, S. \& Burger, M. J. (2020). Extraversion Moderates the Relationship Between the Stringency of COVID-19 Protective Measures and Depressive Symptoms. Frontiers in psychology, 11, 568907.

Wilmot, M., Wanberg, C., Kammeyer-Mueller, J. \& Ones, D. (2019). Extraversion advantages at work: A quantitative review and synthesis of the meta-analytic evidence. Journal of Applied Psychology, 104(12), 1447-1470.

Yolles, M. \& Fink, G. (2013). An Introduction to Mindset Theory. SSRN Electronic Journal,

Youssef, C. M. \& Luthans, F. (2007). Positive organizational behavior in the workplace: The impact of hope, optimism, and resilience. Journal of Management, 33(5), 774-800. 